Ritrýnd grein birt 31. desember 2020

\title{
Sveinspróf í iðnmenntakerfinu: Tímaskekkja eða réttmætt mat á hæfni?
}

\author{
Guðfinna Guðmundsdóttir og Elsa Eiríksdóttir
}

Abstract Um höfunda About the authors $>$ Heimildir

Í peirri rannsókn sem hér er fjallað um eru sveinspróf skoðuð, bæði út frá stöðu peirra sem samfélagsleg viðurkenning á hæfni fagmanns og sem lokamat á námi í iðngrein. Nám til iðnsveins fer fram í tvískiptu kerfi löggiltra iðngreina, annars vegar í skóla og hins vegar á vinnustað. Sveinspróf eru próf atvinnulífsins og tekin eftir að námi í skóla lýkur með burtfararprófi og vinnustaðahluta námsins er lokið. Sveinspróf í iðngrein veita lögvernduð réttindi til að starfa sjálfstætt við greinina og er talið mælikvarði á kunnáttu fagmanns í viðkomandi iðngrein. Markmið rannsóknarinnar er að varpa ljósi á viðhorf peirra sem starfa innan starfsmenntakerfisins, sveina, iðngreinakennara og iðnmeistara til sveinsprófa. Spurt er hvernig sveinspróf tengjast iðnnámi í heild, hvernig innihaldsréttmæti sveinsprófa birtist peim sem nema og kenna iðngreinar og skoðuð er upplifun peirra af próftökuferlinu, með tilliti til undirbúnings, einkunnagjafar og tengsla við burtfararpróf frá skóla. Unnið var úr viðtalsgögnum við 24 kennara, meistara og sveina í fjórum ólíkum iðngreinum. Niðurstöður benda til pess að viðmælendur telji innihaldsréttmæti sveinsprófa ábótavant og oft meti pau ekki pað sem kennt er í náminu í heild, í skóla og á vinnustað. Viðmælendur höfðu ekki allir sömu sýn á til hvaða pátta námsins sveinspróf ætti að ná, en pó voru flestir sammála um að pað væri ekki í takt við kröfur fagsins. Niðurstöður sýna að stjórnsýsla sveinsprófa er flókin og mikilvægt sé að peir sem hagsmuna eiga að gæta vinni og ræði saman til að tryggja réttmæti prófanna. Sveinspróf eiga að tryggja að fullnuma iðnaðarmaður hafi öðlast pá pekkingu, leikni og hæfni sem til er ætlast til að geta starfað sjálfstætt. Skorti pau hins vegar réttmæti gera pau pað ekki.

Efnisorð: Iðnmenntun, iðnnám, sveinspróf, starfsmenntun, framhaldsskóli

\section{Inngangur}

Sveinspróf veita lögvernduð réttindi til að starfa sjálfstætt við iðngrein (iðnaðarlög nr. 42/1978). Pau eru pannig samfélagsleg skilgreining á peirri verkpekkingu sem fagstétt á að búa yfir og mælikvarði á kunnáttu fagmanns í greininni (Ólafur Grétar Kristjánsson, 1995). Sveinspróf hafa lítið verið rannsökuð hér á landi og ekki hefur mikið verið skrifað um stöðu peirra í iðnmenntakerfinu í heild. Markmiðið hér er að varpa ljósi á viðhorf nýlegra sveina, iðngreinakennara og iðnmeistara til hlutverks, inntaks og framkvæmdar sveinsprófa. Sjónum verður beint að hvernig sveinar, kennarar og meistarar sjá sveinsprófin í samhengi við námið í heild, skoðun peirra á útfærslu og innihaldsréttmæti prófanna og upplifun af pví að preyta prófin.

Ætlunin er ekki að skoða innihald sveinsprófa í iðngreinunum eða rýna í prófin sjálf, heldur fjalla um viðhorf til peirra. Um er að ræða viðtalsrannsókn par sem rætt var um sveinspróf við pá sem nema og kenna iðngreinar. Sveinspróf eru annars vegar samfélagsleg viðurkenning á hæfni fagmanns og hins 
vegar lokamat á námi í iðngrein. Mikilvægi sveinsprófa í iðnmenntakerfinu er ótvírætt og pau eru endanlegur úrskurður um hæfni í iðngrein par sem pau veita starfsréttindi.

\section{Iðnnám}

Iðnnám er nám í löggiltum iðngreinum (reglugerð um löggiltar iðngreinar nr. 940/1999) og fellur undir starfsnám samkvæmt Aðalnámskrá frambaldsskóla (Mennta- og menningarmálaráðuneyti, 2012), en starfsnám er notað almennt yfir nám sem undirbýr einstakling fyrir ákveðið starf. Iðnnám fer fram annars vegar í framhaldsskóla og hins vegar á vinnustað undir leiðsögn iðnmeistara. Lokapróf í skólapætti iðnnáms, burtfararpróf, er skipulagt af kennurum á viðkomandi námsbrautum og tekur mið af hæfniviðmiðum aðalnámskrár og námsbrautarlýsingum. Að loknu samningsbundnu vinnustaðanámi og burtfararprófi frá peim framhaldsskóla sem kennir iðngrein getur nemandi sótt um að preyta sveinspróf (lög um framhaldsskóla nr. 92/2008). Sveinspróf eru sjálfstæð próf á vegum atvinnulífsins og veita lögvernduð starfsréttindi í viðkomandi iðngrein. Uppbygging sveinsprófa og inntak er ákveðið í samræmi við markmið Aðalnámskrár framhaldsskóla og uppbyggingu námsins, par með talið skiptingu pess í vinnustaðanám og skólanám (Mennta- og menningarmálaráðuneyti, 2012; reglugerð um sveinspróf nr. 698/2009).

Nemandi sem stenst sveinspróf öðlast löggildingu fagmanns í sinni iðngrein (reglugerð um löggiltar iðngreinar nr. 940/1999), en löggilding byggir á peirri hugmynd að pað varði almannahagsmuni að verk sem krefjast fagkunnáttu séu unnin af fullgildum iðnaðarmönnum (iðnaðarlög nr. 42/1978). Löggild réttindi til að starfa í iðngrein fást eingöngu með pví að preyta sveinspróf.

\section{Hæfniviðmið í ¡ðnnámi}

Í Aðalnámskrá frambaldsskóla (Mennta- og menningarmálaráðuneyti, 2012) er skilgreind sú almenna hæfni sem nemendur purfa að búa yfir að námi loknu í framhaldsskóla, par með talið á prófi til starfsréttinda eða sveinsprófi. Par segir: „Hæfniviðmið starfsnámsbrauta skulu taka mið af kröfu ráðuneytis um lykilhæfni og hæfnikröfur starfa sem starfsgreinaráð viðkomandi starfsgreinaflokks eða starfsgreinar skilgreinir" (bls. 48). Pannig er gert ráð fyrir í Aðalnámskrá framhaldsskóla að starfsgreinaráð skilgreini parfir fyrir pekkingu, leikni og hæfni í tiltekinni grein og námsbrautarlýsingar framhaldsskóla byggi á peirri skilgreiningu. Námsbrautarlýsingar framhaldsskóla fá síðan umsögn starfsgreinaráða í staðfestingarferli. Petta kerfi á að tryggja sameiginlegan skilning á peirri hæfni sem nemi á að tileinka sér í starfsnámi.

Hæfniviðmiðum iðnnáms í heild er lýst í staðfestum námsbrautarlýsingum (Menntamálastofnun, e.d.) og par kemur einnig fram hversu mikið nám fer fram á vinnustað (í eininga- eða vikufjölda) og hvaða áföngum nemendur eiga að ljúka í peim hluta námsins sem fer fram í skóla. Af áfangalýsingum er auðvelt er að sjá hvernig skólapátturinn er uppbyggður. Aftur á móti er ekki eins ljóst hvað nákvæmlega á að gerast í námi á vinnustað; lýsingin á peim pætti er almenn og pví ekki skýrt hvernig unnið er að hæfniviðmiðum námsins í peim hluta. Kennari getur unnið eftir staðfestum námsbrautarlýsingum par sem námið er skipulagt og skilgreint með prepaskiptingum, áföngum og einingafjölda. Hverjum áfanga er síðan nánar lýst með vísun í pá pekkingu, leikni og hæfni sem nemandi á að tileinka sér. Pað getur verið flókið að skilgreina nákvæmlega hvað nemi á að læra á vinnustað par sem vinnustaðanám býður oft uppá óvænta pekkingaröflun í námsferlinu og vinnustaðir geta verið nokkuð sérhæfðir (Atli Harðarson, 2012; Elsa Eiríksdóttir, 2017). Pó hefur verið reynt að skilgreina hvaða hæfni nemar eiga að tileinka sér á vinnustað með námsferilbókum, en peim er ætlað að vera nema til leiðsagnar í vinnustaðanámi (Iðan fræðslusetur, e.d.). Í ferilbókum eru listaðir verkpættir sem nemi á að ljúka og ætlast er til að nemi skrái í hana jafnt og pétt á samningstímanum. Enn sem komið er hefur námsferilbók ekki náð almennri fótfestu í iðnmenntakerfinu, pó að hún sé notuð í sumum greinum (Ríkisendurskoðun, 2017; Védís Grönvold og Sveinn Aðalsteinsson. 2016). Um skeið hefur verið í bígerð að gefa út rafrænar ferilbækur (Mennta- og menningarmálaráðuneytið, 2020; Samtök iðnaðarins, 2019), en pegar petta er skrifað hafa fæstar peirra litið dagsins ljós eða 
fengið skilgreint hlutverk. Staðan er pví sú að skólapáttur iðnnámsbrauta er skýrt skilgreindur í námsbrautarlýsingum en vinnustaðanámshlutinn ekki.

\section{Vinnustaðanám}

Í Aðalnámskrá framhaldsskóla (Mennta- og menningarmálaráðuneyti, 2012) er gerður greinarmunur á starfspjálfun á vinnustað og vinnustaðanámi: „I vinnustaðanámi eru alla jafna gerðar meiri kröfur um markvissa, skipulagða fræðslu, leiðsögn og eftirlit en pegar um starfspjálfun er að ræða. Í starfspjálfun er lögð áhersla á að nemendur fái tækifæri til að pjálfa frekar verkpætti og verkferla sem peir hafi pegar fengið kennslu í ... [og] geti sýnt meiri ábyrgð og sjálfstæði“ (bls. 40). Pegar kemur að námi á vinnustað í löggiltum iðngreinum pá eiga báðar pessar skilgreiningar við, allt eftir iðngreinum, og pví er hér notað orðað vinnustaðanám yfir pann tíma námsins sem nemandi er samningsbundinn á vinnustað. Í reglugerð nr. 840/2011 um vinnustaðanám og starfspjálfun kemur fram að framhaldsskólar eigi að hafa „eftirlit með að nemendur leggi stund á vinnustaðanám sem áskilið er í námskrá" (4. gr.). Hefðin í flestum iðngreinum virðist pó sú að nemendur sjái sjálfir um að koma sér á samning (Elsa Eiríksdóttir, 2017; Ríkisendurskoðun, 2017). Hins vegar hafa kennarar stundum milligöngu um að samningur komist á milli iðnnema og meistara (Elsa Eiríksdóttir, 2017).

Fyrirtæki sem tekur iðnnema á samning skuldbindur sig til að veita nemanda kennslu í greininni. Í reglugerð um vinnustaðanám og starfspjálfun (nr. 840/2011) kemur fram að fyrirtækinu beri skylda til að pjálfa nema og hafa til pess hæfan tilsjónarmann með fullgild iðnréttindi í peirri iðn sem hann hyggst kenna. Pjálfun iðnnema á vinnustað er í höndum iðnmeistara og ber hann ábyrgð á að iðnneminn sé tilbúinn í sveinspróf.

Erfitt getur verið að fylgjast með gæðum vinnustaðanámsins hér á landi par sem ekki er sameiginlegur skilningur á hvað nemi á að læra í pessum hluta námsins, sérstaklega í ljósi pess að ferilbók hefur ekki skilgreint hlutverk í kerfinu. Samkvæmt úttekt Ríkisendurskoðunar (2017) veita hvorki lög, reglur né aðalnámskrá nemendum í starfsnámi leiðsögn eða viðmið um vinnustaðapátt námsins. Á heildina litið virðist lítið eftirlit með vinnustaðahluta iðnnáms og hvort nemar fái pá pjálfun á vettvangi sem til er ætlast (Védís Grönvold og Sveinn Aðalsteinsson, 2016). Petta hefur pær afleiðingar að peir nemar sem eru óheppnir með vinnustaðanám geta lent í peirri stöðu að vera ekki nægilega vel undirbúnir fyrir sveinspróf prátt fyrir hafa lokið bæði skólahluta námsins og tilætluðum tíma eða einingum á vinnustað.

\section{Sveinspróf}

Mennta- og menningarmálaráðherra ber ábyrgð á að haldin séu sveinspróf og að pau endurspegli námskröfur, umfang og skipulag náms samkvæmt aðalnámskrá (lög um framhaldsskóla nr. 92/2008; reglugerð um sveinspróf nr. 698/2009). Samkvæmt 30. gr. laga um framhaldsskóla (nr. 92/2008) er ráðherra heimilt að skipa sveinsprófsnefnd í löggiltum iðngreinum til pess að sjá um framkvæmd sveinsprófa og mat á úrlausnum. Pá getur ráðherra samið við sjálfstæða fræðsluaðila á vinnumarkaði, sbr. 19. gr. reglugerðar um sveinspróf (nr. 698/2009), um að annast framkvæmd og utanumhald sveinsprófa. Hafa slíkir samningar verið gerðir við Iðuna fræðslusetur og Rafmennt svo dæmi séu tekin. Áður en að sveinsprófi kemur eiga nemar að hafa lokið bæði skólahluta námsins með burtfararprófi og tilskildum vikum í vinnustaðanámi. Pó er leyfilegt að ljúka síðustu vikum vinnustaðapáttar eftir að sveinsprófi lýkur, en sveinsbréf er ekki afhent fyrr en öllum páttum er lokið.

\section{Starfsgreinaráð og sveinsprófsnefnd}

Mennta- og menningarmálaráðherra skipar starfsgreinaráð sem eiga samkvæmt lögum (lög um framhaldsskóla nr. 92/2008) að vera ráðherra innan handar með skipulag og framkvæmd sveinsprófa. Starfsgreinaráð skilgreina parfir fyrir kunnáttu og hæfni í starfsgrein og gera tillögur um lokamarkmið starfsnáms og par með sveinsprófa (Ríkisendurskoðun, 2017; reglugerð um skipan og 
störf starfsgreinaráða nr. 711/2009). Starfsgreinaráð gera tillögur til ráðherra um sveinsprófsnefndir sem er síðan falið að sjá um sveinsprófin.

Hver sveinsprófsnefnd er skipuð premur iðnaðarmönnum úr viðkomandi iðngrein til fjögurra ára í senn. Tveir nefndarmanna eru skipaðir að fengnum tillögum starfsgreinaráða og skal annar að jafnaði vera meistari en hinn sveinn. Sá priðji skal skipaður án tilnefningar og skal hann hafa kennslureynslu í iðngreininni, sé pess kostur (reglugerð um sveinspróf nr. 698/2009). Hlutverk nefndarinnar er eftirfarandi:

Sveinsprófsnefnd ber ábyrgð á samningu sveinsprófs og gengur frá peim gögnum sem nota parf við prófið. Sveinsprófsnefnd leggur fyrir skrifleg og verkleg próf. Hún fylgist með vinnutíma próftaka og skráir upphaf og endi vinnutíma hjá hverjum og einum. Á sama hátt skráir prófnefndin á matsblað (atriðalista) vinnulag próftakans, metur og gefur einkunnir fyrir vinnuhraða og verklag. (7. gr. reglugerðar um sveinspróf nr. 698/2009)

Sveinsprófsnefnd ákveður vægi prófpátta, sem og vægi efnisatriða innan hvers prófpáttar. Nefndin skilgreinir jafnframt viðmið um lágmarksárangur í einstökum prófpáttum. Pannig eru starfsgreinaráð og sveinsprófsnefndir með framkvæmd og útfærslu sveinsprófa á sínum höndum.

\section{Framkvæmd sveinsprófa}

Sveinspróf eru haldin að minnsta kosti einu sinni á ári í hverri iðngrein ef næg pátttaka fæst. Í nokkrum iðngreinum eru pau haldin tvisvar á ári, til dæmis í rafvirkjun, en í öðrum eru pau sampætt lokaprófum í skóla, til dæmis í matreiðslu. Sveinspróf fara oftast fram í peim skóla par sem iðngreinin er kennd en pó eru í einhverjum tilvikum haldin sveinspróf í húsnæði fræðslumiðstöðva (Iðan fræðslusetur, e.d.; Rafmennt, e.d.), til dæmis í pípulögnum, rafvirkjun og málaraiðn.

Uppbygging sveinsprófa er mismunandi eftir iðngreinum. Oftast eru bæði verkleg og skrifleg próf, en í einstaka greinum eru eingöngu verkleg sveinspróf. Sveinspróf geta tekið einn til prjá daga eftir umfangi peirra. Yfirseta í prófunum er í höndum sveinsprófsnefndar sem ber einnig ábyrgð á samningu sveinsprófs (reglugerð um sveinspróf nr. 698/2009, 7. gr.) og ákveður úr hverju er prófað. Prófpættir og vægi peirra í verklegum páttum sveinsprófsins eru birtir próftökum fyrir prófið og pannig er hægt að æfa prófpætti fyrir prófið (munnleg heimild frá sveinsprófsnefndarmanni, e.d.). Oftast er gefinn út listi af verkfærum sem próftakar purfa að taka með sér í sveinsprófin. Bóklegur (skriflegur) hluti sveinsprófa er haldinn samhliða verklega hlutanum í flestum iðngreinum. Pessi hluti prófsins er oftast tekinn fyrst en verklegi hluti prófsins í kjölfarið.

Sveinsprófsnefndir fara yfir prófúrlausnir sveinsprófanna og gefin er einkunn fyrir hvern prófpátt (reglugerð um sveinspróf nr. 698/2009). Nemandi skal ná lágmarksárangri í hverjum prófpætti til pess að standast prófið. Einkunn á sveinsprófi byggist á reiknuðu meðaltali prófpátta sem getur verið mismunandi eftir iðngreinum. Til pess að standast sveinspróf parf einkunnina 5 eða $50 \%$ árangur, en 4,5 er gjarnan námundað upp í 5 .

Haldin er prófsýning til að tilkynna próftökum einkunnagjöf úr prófunum og fá nemendur pá að skoða úrlausnir prófa. Nemanda er tilkynnt fyrir prófsýningardag ef hann hefur fallið á sveinsprófinu. Hann á pess kost að endurtaka prófpáttinn sem hann féll í. Misjafnt er eftir iðngreinum hvenær endurtökupróf eru haldin en oft purfa nemendur að bíða eftir að næsta sveinspróf sé haldið í verklega pættinum og getur pá jafnvel liðið heiltár. Ef um skriflega hlutann er að ræða eru endurtökupróf gjarnan fyrr. Sé próftaki ósáttur við niðurstöður matsins og ágreiningur á milli hans og sveinsprófsnefndar getur hann óskað eftir skýringum. Ef ekki tekst að leysa ágreininginn skipar menntamálaráðherra prófdómara til að fara yfir úrlausnina og skal sú niðurstaða gilda. 


\section{Sveinspróf sem lokamat á námi}

Í Aðalnámskrá frambaldsskóla kemur fram að tilgangur námsmats sé að kanna að hve miklu leyti nemandi hefur tileinkað sér pau markmið sem skilgreind eru fyrir tiltekið nám (Mennta- og menningarmálaráðuneyti, 2012). Sveinsprófi er ætlað að meta pá pekkingu, leikni og hæfni sem nemi á að búa yfir til að geta starfað sjálfstætt í grein og á uppbygging pess að vera í „,samræmi við markmið aðalnámskrár og uppbyggingu námsins, p.m.t. skiptingu pess í skólanám og vinnustaðanám“ (reglugerð um sveinspróf nr. 698/2009, 12. gr.). Pannig er sveinsprófi ætlað að vera alhliða mat á pví námi sem iðnneminn hefur lært í skóla og á vinnustað og er pví lokamat (e. summative assessment) á námi. Lokamat hefur pann tilgang að draga saman námsstöðu einstaklinga og leggja dóm á árangur náms og kennslu. Pað er pví formlegur mælikvarði árangur nemanda og á að gefa til kynna kunnáttu hans að loknum námstíma og meta hvort viðhlítandi árangri hafi verið náð (Kilbane og Milman, 2014; Waugh og Gronlund, 2013). Lokamat ákvarðast af markmiðum og parf að endurspegla alla pætti námsins. Pví er mikilvægt að huga að innihaldsréttmæti prófsins í lokamati.

\section{Innihaldsréttmæti}

Pegar gæði í námsmati eru til umræðu er réttmæti (e. validity) lykilhugtak. Réttmæti vísar til pess hvort pað sem átti að meta var í raun metið og hvort pær ályktanir sem dregnar eru af matsniðurstöðum séu merkingarbærar og traustar (Stiggins, 2001). Мeð innihaldsréttmæti (e. content validity) er átt við hvort mat taki til pess innihalds sem á að meta, til dæmis hvort próf sé gott úrtak úr markmiðum náms. Pegar rætt er um sveinspróf er mikilvægt að spyrja hvort pað nái að endurspegla og taka til peirrar hæfni sem iðnaðarmanni í tiltekinni iðngrein er ætlað að búa yfir. Innihaldsmunur getur verið á áherslum vinnustaðanáms og námskrár (Ragnar Wessman, 2010). Petta getur til dæmis átt við pegar pegar pættir sem próftaki hefur unnið við í vinnustaðanámi sínu eru ekki teknir til sveinsprófs, eins og getur gerst par sem fyrirtæki eru sérhæfð. Innihaldsréttmæti vísar til pess að próf endurspegli pá pekkingu, leikni og hæfni sem nemi á að hafa öðlast á námstímanum. Hvernig er pó hægt að tryggja innihaldsréttmæti pegar ekki er ljóst eða sameiginlegur skilningur á hver pessi pekking, leikni og hæfni er? Ekki er óeðlilegt að velta fyrir sér hvort sveinsprófin endurspegli í raun pað nám sem fer fram í hinu tvöfalda kerfi starfsmenntunar, en pað er spurningin sem var lögð fyrir viðmælendur í pessari rannsókn. Hér er pví fjallað um innihaldsréttmæti frá sjónarhorni peirra sem pekkja til iðnmenntunar, en pað ekki greint beint út frá prófgögnum.

\section{Markmið og rannsóknarspurningar}

Mikilvægt er að skoða hvernig sveinsprófin birtast peim sem starfa á vettvangi, pað er peim sem kenna iðngreinar, sinna pjálfun nema og síðast en ekki síst peim sem preyta sveinsprófin. Markmið rannsóknarinnar er pannig að varpa ljósi á viðhorf nýlegra sveina, iðngreinakennara og meistara á vettvangi til hlutverks, inntaks og framkvæmdar sveinsprófa. Til grundvallar liggja eftirfarandi rannsóknarspurningar:

1. Hvernig sjá sveinar, kennarar og meistarar sveinspróf í samhengi við námið sem heild?

2. Hver er skoðun viðmælenda á sveinsprófum sem mati á hæfni iðnaðarmanns, pað er, innihaldsréttmæti prófanna?

3. Hver er upplifun viðmælanda af og skoðun á próftökuferlinu, sérstaklega með tilliti til undirbúnings, einkunnagjafar og tengsla við burtfararpróf frá skóla?

\section{Аðferð}

\section{Pátttakendur}

Pátttakendur í pessari rannsókn voru tuttugu og fjórir, sex úr hverri af peim fjórum iðngreinum sem skoðaðar voru. Pátttakendur skiptast jafnt í prjá hópa: (1) 8 sveinar sem lokið höfðu sveinsprófi í iðngreininni á síðustu tveimur árum áður en viðtölin voru tekin (á aldrinum 21-46 ára, prjár konur 
og fimm karlar), (2) átta meistarar sem höfðu haft tilsjón með nema í vinnustaðanámi á sama tíma (á aldrinum 35-70 ára, prjár konur og fimm karlar) og (3) átta kennarar sem kenna iðngreinina í framhaldsskóla (á aldrinum 35-65 ára, fjórar konur og fjórir karlar). Af pessum 24 pátttakendum bjuggu sex utan höfuðborgarsvæðisins.

Iðngreinarnar fjórar voru valdar sem fulltrúar fyrir tiltekna tilhögun á samtvinnun náms í skóla og á vinnustað og lengd vinnustaðanáms (Elsa Eiríksdóttir, 2017, 2018). Eins var reynt að líta til kynjahlutfalls og velja bæði greinar par sem karlar eða konur eru í meirihluta og grein par sem kynjahlutfall er jafnara. Pátttakendur voru valdir af handahófi úr pýði í hverri iðngrein og pví er um lagskipt tilviljunarúrtak að ræða (e. stratified random sampling) (Bryman, 2012). Upplýsingar um pýði kennara var safnað af heimasíðu framhaldsskóla par sem iðngreinar eru kenndar. Upplýsingar um pýði meistara og sveina voru fengnar hjá peim aðilum sem sjá um vinnustaðasamninga. Starfsmaður sem hafði aðgang að gagnabanka sá um að velja handahófskennt úr peim pýðum. Rannsakendur höfðu samband við mögulega pátttakendur og mæltu sér mót ef pátttaka var sampykkt.

\section{Framkvæmd}

Gögnum var safnað sem hluta af stærri rannsókn á iðnnámi í skóla og á vinnustað (Elsa Eiríksdóttir, 2017, 2018), en hér er aðeins unnið með pann hluta gagnanna sem snýr að sveinsprófum. Prír rannsakendur sáu um að taka öll viðtölin. Fyrsti höfundur tók ekki viðtölin en fékk aðgang að orðréttum afritunum. Viðtölin voru einstaklingsviðtöl og tekin veturinn 2014-2015, flest á vinnustöðum viðmælanda. Lengd viðtala var á bilinu 35 til 75 mínútur. Öll viðtölin voru tekin upp og síðan skrifuð upp til greiningar. Upptaka á einu viðtalinu misfórst og skrifaði rannsakandi upp nótur úr viðtalinu eftir minni.

Notaður var hálfopinn viðtalsrammi par sem spurt var um samspil bóklegra og verklegra greina í skólapætti námsins, samspil náms á vinnustað og í skóla, ferilbók, sveinspróf og grundvallarfærni í faginu. Áður en viðtölin voru tekin var viðtalsramminn prófaður og rýndur af tveimur iðnmenntuðum einstaklingum. Рað leiddi til breytinga á orðavali og röðun spurninga. Til að auka réttmæti rannsóknarinnar hittust rannsakendur reglulega, sérstaklega í upphafi gagnasöfnunar, ræddu orðalag og mögulegan misskilning og nálgun. Viðtalsrammi rannsóknarinnar var aðlagaður að hverjum hópi, en allir fengu sambærilegar spurningar.

Viðmælendur skrifuðu undir upplýst sampykki og var rannsóknin tilkynnt til Persónuverndar.

\section{Greining gagna og siðferðislegir pættir}

Viðtölin voru pemagreind við úrvinnslu (Braun og Clarke, 2006, 2013) og pemun flokkuð til pess að fá sem besta heildarmynd af viðhorfum til og reynslu pátttakenda af sveinsprófum. Fólst greiningarvinnan í að skapa mynstur og kóða til að fá röklegt samhengi af pemum gagnasafnsins. Pemagreining Braun og Clarke (2006) skiptist í sex skref par sem byrjað er á smáum einingum og pær lagðar saman til pess að mynda stærri einingar. Í pessu ferli voru gögnin lesin og endurlesin gaumgæfilega og merkt við pað sem við kom viðfangsefninu. Efnið var kóðað í samhengi við rannsóknarspurningar og kóðunum gefin lýsandi heiti. Að pví loknu voru kóðar um svipað efni flokkaðir í pemu. Pemun voru rýnd og gaumgæfð með tilliti til samhengis, hvert pema var skilgreint, gefið nafn út frá innihaldi og lýsandi brot út gögnunum nýtt til að varpa ljósi á pemun. Í niðurstöðum er gerð grein fyrir peim pemum sem komu fram í viðtalsgögnum út frá rannsóknarspurningunum sem lagðar voru til grundvallar.

Viðmælendum í rannsókninni var heitið trúnaði og af peirri ástæðu verður ekki gerð grein fyrir hvaða iðngreinum pátttakendur tilheyrðu eða um hvaða skóla eða vinnustaði er rætt. Iðngreinarnar eru gjarnan fámennar og pví auðvelt að leiða líkum að hverjir viðmælendur eru út frá litlum upplýsingum. Pví er leitast við að gefa eins lítið upp um viðmælendur og hægt er. Ekki er sagt frá aldri, starfsreynslu eða hvenær viðmælendur útskrifuðust. Vísað er til allra viðmælendanna með dulnefnum (sjá Töflu 1). 
Tafla 1. Dulnefni viðmælenda eftir hópum.

\begin{tabular}{ccc}
\hline Sveinar & Kennarar & Meistarar \\
\hline Andri & Álfrún & Guðrún \\
Brá & Björn & Gunnar \\
Máni & Didda & Helga \\
Már & Kristján & Ívar \\
Sóley & Róbert & Jón \\
Sólrún & Veiga & Sigurður \\
Stefán & Vilborg & Una \\
Steinn & Pórður & Ýr \\
\hline
\end{tabular}

\section{Niðurstöður}

Farið verður yfir niðurstöður í samhengi við rannsóknarspurningarnar prjár og pau pemu sem peim tengjast. Fyrst verður farið yfir hvernig viðmælendur sjá sveinspróf í samhengi við námið sem heild. Síðan verður fjallað um viðhorf viðmælenda til sveinsprófa sem mat á hæfni iðnaðarmanna, pað er skoðun peirra á innihaldsréttmæti prófanna. Að lokum verður fjallað um viðhorf viðmælenda til framkvæmdar sveinsprófanna, með tilliti til undirbúnings fyrir prófið, mats og einkunnar og tengsl við burtfararpróf frá skóla.

\section{Iðnnámi sem heild lýkur með sveinsprófi}

Í tveimur af fjórum iðngreinum sem hér er fjallað um virðist hafa reynst mjög erfitt fyrir nema að komast í vinnustaðanám. Petta pýðir að oft getur liðið langur tími frá pví að nemar ljúka skólapætti námsins par til peir komast á samning, „ef peir pá komast á samning“ eins og Una meistari komst að orði. Álfrún kennari í greininni kom einnig inn á petta vandamál: „Mér finnst pað galli að pað auðvitað geta ekki allir fengið starfspjálfunarpláss sko," segir hún og bætir við að hún hafi frétt af einni sem hafi verið að fá samning nú ári eftir að hafa lokið skólanámi. Námssamningur á vinnustað er grundvöllur pess að nemar geti lokið sveinsprófi og verður pað að teljast afar óheppilegt að iðnnemar purfi sjálfir að leita eftir samningi sem óvíst er að peir fái. Í flestum iðngreinum er sá háttur hafður á að nemar purfa sjálfir að leita sér að námssamningi pegar peir hafa útskrifast úr framhaldsskólanum. Vandamálið er að boðið er upp á nám í framhaldsskólum sem ljúka á með sveinsprófi, en eins og Vilborg kennari orðaði pað: „Til hvers að vera að bjóða upp á nám sem ekki er hægt að klára, pað er vöntun á [fagfólki] í stéttinni ... ef við útskrifum engan, pá endar petta með pví að verða bara ófaglærðir." Ekki eru allir sammála um að vandamálið sé skortur á samningsplássum, heldur geti vandamálið einnig verið skólinn. Guðrún meistari nefndi að skólarnir tækju of marga nema inn par sem fjárframlög til skólanna byggðist á nemendafjölda. Helgi meistari sagði: „Af pví að peir fá einhverjar X krónur fyrir hvern nemenda ... rosalegt brottfall úr stéttinni ... pað er svo erfitt að komast á samning."

Skólapáttur námsins getur einnig verið flöskuháls par sem ekki er alltaf pláss fyrir alla nemendur sem sækja um. Jón meistari sagði: „Skólinn er bara of lítill ... Ég er með nema sem getur ekki klárað vegna pess að hann komst ekki inn í [áfanga]." Einnig benti Sólrún nemi á að tilteknir áfangar væru jafnvel ekki kenndir í skólanum vegna pess að ekki væru nógu margir nemendur skráðir. Petta leiðir til pess að námi seinkar. Sveinar í pessum iðngreinum sögðu að pað yrði oft til pess að nemar hættu námi. Рað voru eðlilega sveinarnir sem höfðu hvað mestar áhyggjur af flöskuhálsum í náminu. Peir nefndu að ekki væri gott að purfa að seinka námi vegna pess að hluti pess væri ekki í boði pegar peir ættu að taka hann. Sérstaklega töluðu sveinarnir um vinnustaðanámið. Sólrún sveinn sagði: „Við vorum 24 og vorum fjögur sem náðum samningi.“ 
Viðmælendur vöktu gjarnan í pessu samhengi máls á hvar ábyrgðin á framkvæmd og útfærslu námsins í heild ætti að liggja. Bent var á að fjöldi nemenda gæti ekki klárað nám sitt vegna pess að flöskuháls gæti myndast, bæði í skóla- og vinnustaðahluta iðnnámsins. Til að fá að starfa við iðngrein parf að standast sveinspróf, og ekki er hægt að preyta sveinspróf nema bæði skólahluta og vinnustaðanámi sé lokið. Nemendur sem lenda á milli í kerfinu hafa fáa kosti með óklárað nám. Viðmælendur bentu á að pað væri mjög slæmt fyrir greinina að vera með fjölda manns með hálfklárað nám og enga löggildingu til að vinna við fagið.

Að auki getur tímasetning sveinsprófanna skapað vandamál fyrir nemendur. Oft eru sveinsprófin einungis haldin einu sinni á ári og ef nemendur hafa ekki lokið námi á hagstæðum tíma til að taka prófið getur myndast töluvert bil, eins og Una meistari sagði: „Рau purfa að bíða í heilt ár eftir pví að fá að taka prófið ... [eru] jafnvel ekki að vinna við fagið, búin með vinnustaðanámið og fá ekki áframhaldandi vinnu.“ Hún bætir við: „Á pessu heila ári týnist margt. Tala nú ekki um ef pú ferð að vinna eitthvað annað en við fagið.“ Sóley, sveinn í greininni, lýsti sinni sveinsprófstöku pannig: „Ég tók sveinsprófið í maí, var ekki alveg búin með samninginn en var heppin, pað hefði verið leiðinlegt fyrir mig, pað hefði munað mánuði og pá hefði ég purft að bíða í ár eftir að taka sveinsprófið.“

Ýmislegt getur pannig valdið pví að nemendur heltist úr lestinni á leiðinni í gegnum iðnnám að sveinsprófi. Eins og kerfið er nú byggt upp eru skóli, vinnustaðanám og sveinsprófið prír óháðir hlutar námsins, og ef nemi er óheppinn geta myndast bil sem erfitt er að brúa.

\section{Sveinspróf sem mat á hæfni - viðhorf til innihaldsréttmætis}

Til pess að sveinsprófið geti gegnt hlutverki sínu sem heildstætt lokamat og staðfesting á kunnáttu í iðngrein verður innihaldsréttmæti pess að vera tryggt. Pað er pví ekki óeðlilegt að spyrja hvað liggur til grundvallar sveinsprófinu og hvort pað meti í raun pað sem nemendur hafa lært í gegnum námið, bæði í skóla og á vinnustað.

\section{Inntak sveinsprófa: Hvað á að meta?}

Viðmælendur voru ekki á sama máli pegar kom að umræðu um inntak sveinsprófa og hvað pau ættu að mæla. Margir viðmælendur voru gagnrýnir á innihald prófanna og töldu pað ekki vera í takt við kröfur fagsins. Til dæmis sagði Didda kennari: „Рað er verið að prófa í einhverju sem er bæði gamaldags annars vegar og síðan er hins vegar að pað er verið að prófa í einhverju sem nemendur nota aldrei." Hún telur að par sem petta er svona pá purfi kennarar að undirbúa nema sérstaklega fyrir prófið svo peir komist í gegn; „ég djöflast í peim í tvær vikur fyrir sveinspróf að kenna peim petta“. Stefán sveinn tók undir petta: „Svo voru pættir sem ... ég hef aldrei séð gerða áður, nema á einhverjum 30-40 ára gömlum myndum kannski ... Margt af pví sem prófað er úr er ekki kennt á vinnustaðnum og ég á aldrei eftir að gera petta." Meistarar voru almennt sammála um að sveinsprófið væri ekki alveg í takt við kröfur fagsins. Pó bentu sumir viðmælendur á að sérhæfing iðngreina skipti hér máli, pví oft væri mikil sérhæfing á vinnustöðum. Pannig væri ekki endilega hægt að prófa úr pví sem nemar læra á vinnustöðum og áherslan ætti að vera á faglega undirstöðufærni nemans.

Viðmælendur voru ekki endilega sammála um til hvaða pátta prófið ætti að ná. Sumir bentu á að ekki væri hægt að meta mikilvæg atriði vegna pess að pau væru of flókin og umfangsmikil til pess að rúmast innan próftímans. Gunnar meistari velti fyrir sér hvort sveinsprófið ætti ekki eingöngu að taka til verklegra pátta: „Pað er ekki í takt að vera með petta bóklega ... skólinn á að sjá um bóklega hlutann, sveinsprófið verklegt eingöngu, kanna verkhæfni manna." Vilborg kennari taldi slæmt að ekki væri prófað úr öllum peim páttum sem æskilegt væri að nemar hefðu hæfni í: „Eins og [námspáttur] sem er kannski svolítið dottið upp fyrir, eða minna um pað, pá finnst mér samt svona sem atvinnuréttindapróf að pú purfir að taka próf í pessum pætti, petta er stór páttur í faginu.“

Ágreiningur um hvað eigi að meta á sveinsprófi virtist pví algengur, en sneri einnig að hvort ljóst væri fyrirfram til hvaða pátta fagsins prófið næði. Sigurður meistari sagði: „[Peir í sveinsprófsnefndinni] 
hafa bætt við [páttum] án pess að láta vita fyrirfram og allt fór í uppnám, nemendur kunnu ekkert pessa aðferðafræði sem lá að baki.“ Kristján kennari tekur undir petta sjónarmið: „Við vorum að krítisera, hvað er, til hvers eruð pið að spyrja að pessu? Hvernig viljið pið fá svarið við pessu?" Pannig töluðu viðmælendur um að oft mætti alveg búast við einhverju óvæntu á prófinu, jafnvel einhverju sem ekki væri ástæða til að ætla að nemendur hefðu lært. Einnig töluðu viðmælendur um mun á einstökum prófpáttum á milli ára. Brá sveinn sagði petta:

Sko nærri allur okkar bekkur féll í fyrsta skiptið ... Svo tókum við petta öll aftur. Pá í rauninni var [pað sem hún féll í] miklu verra en verið hafði áđur. Ég sá pað bara en ég fékk mjög háa og fína einkunn, mér fannst pað mjög spes ... ég hugsaði bara, ok hugsaðu eins og prófnefndin, gerðu bara smá... og pá vissi ég alveg að ég var að blikka pau.

Andri sveinn var ekki heldur sáttur við verklega hluta sveinsprófsins sem hann preytti: „Pá var ég að [lýsir verkpætti] pá fékk ég mínusstig fyrir pað. Pá spurði ég hann af hverju, petta væri gert svona á vinnumarkaðinum. Hann sagði já ég veit pað, en við gerum ekki svona hér.“ Parna virðist dregið niður á prófi pegar verkpáttur er unninn eins og tíðkast úti á vinnumarkaði. Vilborg kennari benti einnig á misræmi í mati á prófum skólans og sveinsprófsnefndar og pví til stuðnings sagði hún:

Sveinsprófsnefndin parf að vera með alveg á kristalstæru hvað pað var sem var að í úrlausn nemans. Af pví að pau fá bara fall, bara F, pau gefa ekki tölur. Parna er ósamræmi við pað sem skólinn er að gera ... pau bentu á tvo hluti sem voru að og nemandinn fékk fall. En til dæmis í námsmati í skólanum hjá okkur, pá er petta ekki fall pó pað dragi vissulega einkunn niður um ákveðin prósent ... ekki fall.

Á heildina litið eru viðmælendur ekki á einu máli um hvað sveinspróf eigi að mæla: Hæfni sem er í takt við fagið eins og pað er á vinnumarkaðinum eða hæfni sem iðnaðarmaður í faginu „á“ að hafa, hvort sem hún er almennt í notkun eða ekki. Ljóst er af orðum viðmælenda að peim finnst sveinspróf oft ekki meta pá hæfni sem neminn hefur öðlast á námsferlinum og leiðir pað til pess að neminn parf að æfa pá pætti sérstaklega fyrir prófið. Í máli viðmælenda í einni iðngreininni kom fram að lokaönn í skólapætti námsins væri í raun æfing fyrir sveinsprófið. Pannig er litið á lokaönnina í skólanum sem öryggisventil á vinnustaðanámið. Ef nemandi hefur ekki öðlast pjálfun á vettvangi í tilteknum pætti, pá er parna tækifæri til að vinna pað upp. Auðvitað byggir pað skipulag pó á að vitað sé hvaða pættir komi á sveinsprófi.

\section{Höfundar prófanna: Sveinsprófsnefnd}

Sveinsprófsnefndir sjá um að semja og fara yfir sveinsprófin. Í viðtölunum kom fram að lítið væri um formlega samvinnu eða samtal milli fulltrúa í sveinsprófsnefnd, kennara og meistara í iðngreinunum. Sumir voru mjög gagnrýnir á störf sveinsprófsnefnda og skort á samstarfi, Kristján kennari sagði:

Ég var mjög óhress með sveinsprófsnefndina hjá okkur, peir litu á petta sem einhver leyndarmál og petta var allt lokað hjá peim, peir sýndu ekki nein próf og ég mátti ekki sjá nein próf hjá peim ... við vorum mjög ósáttir við ýmislegt sem spurt var um parna, sem okkur fannst bara beinlínis vitlaust.

Pórður kennari lýsti pví sem gæti gerst pegar samskiptin væru ekki til staðar:

Рað var pannig fyrir x mörgum árum, ég held að pað hafi farið upp í 70\% fall á sveinsprófi. Pá var skólinn og sveinsprófsnefndin, pað var ekkert að vinna saman sko. Skólinn var með pessar kröfur og svo kom sveinsprófsnefnd með allt aðrar hugmyndir og svo hérna var á milli 40-70\% nemenda sem féllu bara. Pað eru pessir tveir turnar sko.

Ljóst er að kennarar, meistarar og sveinsprófsnefnd ganga oft ekki í takt. Velta má fyrir sér hvernig sveinspróf geti verið réttmætt mat á peirri hæfni sem neminn hefur tileinkað sér á námstímanum ef lítil samskipti eru á milli peirra sem semja prófin og peirra sem sjá um kennslu greinarinnar. 
Pó eru merki um að petta sé að breytast og nokkrir kennarar nefndu að fundir væru haldnir með sveinsprófsnefndum pegar liði að prófunum. Álfrún kennari benti á að í hennar iðngrein væru aðilar farnir að hittast: „Já, já. Við höldum saman fundi, sveinsprófsnefndin og kennararnir, til að aðeins að samræma okkur og sveinsprófsnefnd." Einnig kom fram að pegar samtal á sér stað á milli pessara aðila pá græða allir. Róbert kennari sagði:

Рað er nefnilega pannig að á undan prófi kemur nám ... Sveinsprófsnefndin hefur svo marga snertifleti úti í atvinnulífinu og pessi samtöl [kennara og sveinsprófsnefndar] sem eiga sér stað á pessum fjórum til fimm dögum [fyrir sveinsprófið] eru svo innihaldsrík og áköf að pað verða oft góðar niðurstöður.

Róbert taldi að í hans fagi hefði verið talað saman og komist að niðurstöðu um framkvæmd og útfærslu á prófinu. Petta dæmi sýnir mikilvægi pess að samskipti séu milli aðila sem koma að náminu, en svo virðist sem tengsl sveinsprófsnefnda séu frekar byggð á persónulegum kynnum, en ekki formgerð eru í kerfinu.

Í pessu samhengi skiptir máli hverjir sitja í sveinsprófsnefnd og tengsl peirra við bæði skólana og atvinnulífið. Sumir viðmælendur voru mjög gagnrýnir á takmarkaða endurnýjun í nefndunum. Didda kennari sagði: „Petta eru bara gamlir karlar og búnir að vera parna í 20 ár. Pað parf að hrista upp í pessu ... ekkert í takt við pað sem er að gerast í faginu.“ Og hún bætti við: „Pessir aðilar sem eru í sveinsprófsnefndinni parna peir hafa ekki komið nálægt faginu í tuttugu ár. Af hverju er petta látið viðgangast?" Una meistari tók undir pessa afstöðu og benti á að í sveinsprófsnefndinni væru bara karlar, og sagði um nefndina:

[Peir] vinna kannski ekki alveg við petta svona per se, við fagið, kannski komnir meira á skrifstofu, ég veit pað ekki alveg. Petta er búið að vera eins dálítið í mörg ár og kannski ekki alveg eins og markaðurinn er í dag ... annaðhvort parf að endurskipuleggja petta allt saman eða hætta pessu.

Á námstímanum kemur sveinsprófsnefndin hvergi nærri náminu, en kostur væri að nefndin færi í heimsóknir bæði í skóla og á vinnustaði og fylgdist með pví námi sem par á sér stað. Jafnvel væri hægt að meta til sveinsprófs einstaka námspætti við raunverulegar aðstæður á vinnustöðum nema. Afstaða viðmælendanna til pess hvað pyrfti til að framkvæmd og mat á sveinsprófum yrði skilvirkara var ljós: Samtal peirra sem að sveinsprófunum koma parf að verða formlegt og skýrt auk pess að samskiptin eiga að vera til staðar á námsferlinum öllum.

\section{Að taka sveinspróf}

Í viðtölunum var spurt um ferlið við og reynsluna af að taka sveinspróf. Sérstaklega var rætt um undirbúning fyrir sveinspróf, einkunnagjöf og tengslin milli burtfararprófs frá skóla og sveinsprófsins.

\section{Undirbúningur fyrir sveinspróf}

Pegar viðmælendur voru spurðir hvort nemendur hefðu verið sérstaklega undirbúnir fyrir sveinsprófið á námstímanum kom fram að undirbúningur hæfist á seinni hluta námstímans og pá helst í skólapætti námsins. Skólinn sér pá um að pjálfa námspætti sem nemar hafa ekki fengið pjálfun í á vinnustað. Petta kom fram í premur af fjórum iðngreinum. Í sumum tilvikum er lokaönn í skóla notuð sem undirbúningur fyrir sveinspróf, en í öðrum eiga nemendur kost á námskeiði í skólunum til að undirbúa sig fyrir prófið. Sveinarnir töluðu um að áhersla væri á að æfa sig á ákveðnum páttum og sérstök áhersla væri á að kenna hluti sem væru á atriðaskrá sveinsprófsnefndar.

Í einni iðngrein par sem erfitt er að fá samning og langt getur liðið á milli loka vinnustaðanáms og sveinsprófs fara nemendur á námskeið. Kristján, kennari í faginu, benti á að par sem langt getur liðið milli pess að nemarnir ljúki námi í skóla par til peir fara í sveinsprófið, væru nemar oft búnir að gleyma einhverjum páttum námsins sem peir eru ekki að vinna við. Hann sagði: „Við höldum 
hálfs mánaðar undirbúningsnámskeið par sem er rifjað upp svona samantekið allt saman sem okkur dettur í hug að komi á sveinsprófi.“ Báðir sveinarnir í greininni sögðu að nauðsynlegt hefði verið að komast á námskeið fyrir prófið og annar, Andri, sagði: „Ég hefði aldrei náð sveinsprófinu nema af pví að ég fór á námskeið. Maður er búinn að gleyma alls konar ... maður rifjar allt upp.“

Skólinn virðist almennt bera meiri ábyrgð á beinum undirbúningi fyrir sveinspróf en vinnustaðir. Sveinarnir voru nær allir sammála um að ekki væri mikil áhersla á að undirbúa pá fyrir sveinspróf á vinnustöðum. Nemar væru mikið á eigin vegum, en fengju hjálp ef peir bæru sig eftir henni, eins og sveinninn Andri lýsti:

Já peir voru alveg að undirbúa mig, létu okkur gera ... alls konar svoleiðis dót, pað var ekki beint verið að fylgjast með einhverju handbragði eins og gert er á sveinsprófinu, maður purfti bara að rifja petta upp sjálfur.

Meistarar virðast ekki leggja mikla áherslu á beinan undirbúning. Ýr meistari sagði til dæmis að hún ætlaðist að sjálfsögðu til að hennar nemar næðu sveinsprófinu með glans en sagðist ekkert endilega undirbúa pau sérstaklega fyrir prófið. Stefán sveinn lýsti hvernig hann hefði sjálfur sett upp æfingaplan fyrir sveinsprófið:

Ég ég undirbjó mig persónulega mjög vel ... fékk að æfa mig í vinnunni svo hafði ég samband við [fyrirtæki] og fékk að æfa og læra hjá peim [námspætti] sem ekki voru í vinnunni ... ég mætti hjá peim í tvær vikur til pess að æfa hraðann í verkferlinu. Fyrst pegar ég byrjaði var ég eina klukkustund [með einn prófpátt] en var kominn niður í átta eða tíu mínútur pegar ég fór í prófið.

Parna lýsir Stefán hvernig hann fær aðgang að efni og tækjum til undirbúnings en pað virðist einmitt algengt að nemar fái tíma og aðstöðu til að æfa sig. Рað kom fram hjá Jóni meistara: „Já, pau koma í vinnuna og æfa sig og við borgum hráefnið allt í pað“ og Ívar, annar meistari, sagðist hafa gert æfingaaðstöðu til peirra verka sem menn væru að falla mest í á sveinsprófinu. Una meistari svaraði spurningunni um hvort hún skoðaði sína pjálfun að einhverju leyti í samhengi við sveinsprófið, pað er hvort hún tæki mið af pví í pjálfun nemans. Hún svaraði:

Nei í rauninni ekki. En við svona reynum ... ég er alltaf að hamra á pví að pau æfi sig fyrir prófin, ég hef líka hvatt pau til að til að ... af pví að við erum alltaf með nema frá síðasta ári sem eru pá bara eitt ár síðan pau fóru í próf. Að tala saman og láta hin sem sagt að fara með nýja nemandanum í gegnum, hvað er farið í gegnum á sveinsprófi. Pannig að pau eru betur undirbúin undir ... sveinsprófið.

Af pessu má sjá að meistarar nálgast undirbúning fyrir sveinsprófið á ólíka vegu og virðist hlutverk meistara stundum ekki skýrt í pessu samhengi. Pað vekur spurningar um hlutverk kennara og meistara í ferlinu. Eins virðist munur á greinum, í sumum hefur undirbúningur fyrir sveinsprófið verið formgerður í skólanum en í öðrum virðist neminn meira á eigin vegum.

Einkunn á sveinsprófi: „Finnst pér 4,5 i lagi?“

Einn peirra pátta sem viðmælendum var tíðrætt um var einkunn á sveinsprófi. Viðmælendum fannst einkunnin 4,5 mjög lág, fannst ekki ásættanlegt að útskrifast með lágmarkseinkunn og lítill metnaður í faginu ef petta væri látið duga. Már sveinn sagði:

Mér finnst pað of lágt. Pú parft náttúrlega að kunna pað sem pú ert að útskrifast úr. Eins og núna, pá voru verkefnin einföld og pegar var verið að spyrja út í af hverju petta væri svona einfalt að pá var sagt: Nemarnir eru svo mislangt komnir í námi að pað er verið að leyfa öllum að sýna hvað peir geta. Mér finnst petta svolítið slappt pað er verið að hleypa of mörgum í gegn. Sem er ekki gott fyrir fagið, pað voru rosalega margir sem sögðu, ég ætla bara að ná. 
Viðmælendur voru flestir á peirri skoðun að sveinsprófið væri skilgreint sem próf par sem próftaki hefði náð tiltekinni færni eða tökum á ákveðnu viðfangsefni, iðngrein. Petta var mikilvægt að mati viðmælenda og voru flestir sammála um að kröfur væru ekki nægilegar. Róbert kennari benti á að ef sveinsprófið er skilgreint sem leiknipróf (e. mastery test), par sem nemanda er ætlað að sýna fram á að hann hafi náð tökum á tilteknu viðfangsefni, pá ætti ekki að vera nóg að ná aðeins $50 \%$ af prófinu, hvað pá 45\% eins og stundum er tekið gilt. Pað pyrftu að vera skýrar og metnaðarfullar kröfur um ásættanlegar einkunnir og færni í faginu. Sveinarnir töldu bað skjóta skökku við að hægt væri ná sveinsprófi, án pess að hafa undirstöðufærni í mikilvægum páttum fagsins eða eins og Már sveinn sagði varðandi kröfur:

Mér finnst rosalega slæmt að pað komi einhver í sveinspróf sem aldrei hefur gert [nefnir nokkra pætti]. Mér finnst pað ekki eiga að vera. Samt getur sú manneskja komist í gegnum sveinspróf og náð, vegna pess að pað eru svo litlar kröfur. Ég verð eiginlega reiður stundum pegar ég fer að tala um petta, hvað pað eru litlar kröfur gerðar til okkar.

Sóley nemi benti á: „Mér fannst sko sveinsprófið pannig að hleypa kannski nemendum sem eru ekki hæfir of auðveldlega í gegn.“

Fleiri viðmælendur ræddu kröfur á prófinu og hvort pað gæfi raunhæfa mynd af stöðu pekkingar: Ýr meistari velti fyrir sér hvernig sumir kæmust í gegnum sveinspróf á meðan aðrir féllu. Pá benti hún á að ef til vill væri betra að vera aðeins með símat í stað pessa prófs: „Ég er í sjálfu sér að hallast að pví sérstaklega í fullorðinsnámi að pað purfi ekki endilega að taka próf.“

Sveinsprófið er lokapróf og staðfesting pess að sá sem hefur náð prófinu geti unnið í löggiltri iðngrein par sem krafist er sérfræðipekkingar. Pví eru áhyggjur viðmælenda af kröfum um lágmarkseinkunn skiljanlegar. Eins og umræðan um innihaldsréttmæti gefur til kynna pá er pó einnig spurning hvort einkunnin sýni raunverulega pá hæfni sem iðnsveinninn býr yfir pegar hann fer út á vinnumarkaðinn sem löggildur sveinn. Erfitt er að áætla hvað einkunn merkir pegar réttmæti prófs er á reiki.

\section{Sveinspróf og burtfararpróf: "Bara nákvemlega eins“}

Viðmælendur ræddu hlutverk burtfararprófs frá skóla og tengsl pess við sveinspróf. Burtfararpróf eru haldin á síðustu námsönn í framhaldsskóla í flestum iðngreinum og eru oftast bæði verkleg og skrifleg próf líkt og sveinsprófin. Burtfararpróf eru pannig lokapróf úr skólapætti námsins en sveinspróf eru tekin eftir að báðum hlutum námsins er lokið. Flestir viðmælendur voru á peirri skoðun að pessi tvö próf ættu ekki að ná til sömu pátta, en af ólíkum ástæðum eftir tímasetningu prófanna. Par sem langur tími líður á milli burtfararprófs og sveinsprófs var rætt um að ekki væri rétt að prófa sömu hlutina. Gunnar meistari sagði:

Svo kemur aftur á móti pegar sveinsprófið kemur, pá er hluti af pví sem peir voru með í skólanum, hann er tekinn með í sveinsprófið og eftir tvö ár eru menn náttúrulega búnir að gleyma pví stór hluti af pessu er bara í svona bókum sem við erum með.

Hér er Gunnar að vísa í að langur tími geti liðið á milli pess sem nemarnir taka burtfararpróf og sveinspróf, sem gerist til dæmis par sem erfitt er að fá námssamning eða vinnustaðanám fer að stórum hluta fram eftir að skóla er lokið. Einhverjir sveinar voru á peirri skoðun að pessi tvö próf ættu að gegna ólíku hlutverki í pessu samhengi. Máni sagði til dæmis:

Að sveinsprófið ætti að vera prufa í pví hvað pú ert búinn að læra á vinnumarkaði. Pað er búið [skólaprófið], pú ert búinn að taka prófið úr skólanum, pess vegna á meira að einblína á pað sem pú ert að læra á vinnumarkaðinum heldur en allt petta bóklega, sko.

Sólrún, annar sveinn, sagði: „Fyrir mig hafði pað pýðingu að útskrifast úr náminu, sjálfu náminu, pá er maður búinn með pað, en sveinsprófið, pá ertu búin með námssamninginn og pá ertu einhvern veginn fulllærð." Pannig fannst sveinum prófin tvö endurspegla tvískiptingu námsins í skóla og á vinnustað. 
Í öðrum greinum fara burtfararpróf og sveinspróf fram á sama tíma og par ræddu viðmælendur gjarnan um óparfa endurtekningu. Pannig velti Guðrún meistari fyrir sér tilgangi pess að prófa úr mörgum páttum í tveimur prófum og benti á að mikil spenna væri milli kennara í skólanum og sveinsprófsnefndar um hvað ætti að prófa og hver höndin væri upp á móti annarri: „Mér finnst svolítið skrýtið að pau skuli ekki setja sig í spor nemenda.“ Annar meistari, Ýr, sagðist ekki skilja hvert hlutverk burtfararprófs væri. Hún sagði að petta væri eins og eitthvert málamiðlunarpróf: „Аð einhver hafi fallið á burtfararprófi og sé látinn taka bekkinn aftur, væri ekki betra að prófa bara allan veturinn?"

Peir kennarar sem talað var við voru ekki allir á sama máli. Fram kom hjá Vilborgu að henni fyndist pessi endurtekning gagnleg: „Petta er bara sama prófið. Generalprufa, pað má kalla pað pað.“Veiga sem er kennari í sömu iðngrein sagði að henni fyndist burtfararpróf tékklisti: „Ertu búin að - að læra alla pessa pætti." Svo bætti hún við að á burtfararprófi væri verið að prófa í mörgum páttum sem ekki væru á sveinsprófi. Didda kennari nefndi að gott væri ef nemarnir gætu farið nánast beint í sveinspróf eftir útskriftina frá skóla: „Рað er besta leiðin, nemendur útskrifist héðan úr skólanum um áramót og fara síðan í sveinsprófið í febrúar, pá eru peir bara búnir með sitt nám.“

Sveinarnir voru almennt ekki hrifnir af pessum tvöföldu prófunum og töluðu um óparfa endurtekningu. Sóley sveinn sagði til dæmis: „Svo í rauninni kom ég í sveinsprófið og pá var bara, sveinsprófið var eiginlega bara nákvæmlega eins og burtfararprófið frá skólanum ... ég hélt að sveinsprófið yrði miklu erfiðara, mér fannst pað mjög létt miðað við hvað ég hélt að pað yrði.“ Brá, annar sveinn, tók undir petta: „Mig minnir að mér hafi fundist petta eitthvað ferlega bjánalegt. Einhver svona tvöföld útskrift ... Svo í rauninni kom ég í sveinsprófið og pá var bara, sveinsprófið var eiginlega bara nákvæmlega eins og burtfararprófið. "Máni sveinn sagði að hann hefði ekki orðið betri fagmaður pótt hann tæki bæði pessi próf. „Sveinsprófið bætir ekki neinu við burtfararprófið,“ sagði hann.

Í einni iðngrein fara burtfararpróf og sveinspróf fram á sama tíma og par er mat í bóklegum áföngum skólans látið gilda í bæði burtfarar- og sveinsprófi, en Róbert, kennari í peirri iðngrein, sagði: „Lokapróf [í skóla] og sveinspróf er sameiginlegt, pað er, allt okkar mat er símat og pað er verið að meta alla önnina." Í pessari iðngrein er verklega burtfararprófið og sveinsprófið sama prófið, tveggja daga próf sem er bæði metið af kennurum og sveinsprófsnefnd. Parna hafa pessi lokapróf í raun verið sameinuð og fara fram pegar náminu í heild lýkur.

Í umræðu um pessi tvö próf voru viðmælendur almennt sammála um að æskilegt væri að sveinsprófið tæki meira mið af vinnustaðapættinum og flestum fannst að sveinsprófið ætti einungis að vera verklegt, en oftast er einnig bóklegur páttur í prófinu. Skólinn útskrifar nema með burtfararpróf og par er áherslan gjarnan á bóklega hlutann, pó að pað sé líka oft verklegt.

Áhugavert er að hefð sé fyrir pví að hafa tvö lokapróf í iðnnámi, annað á vegum skóla og hitt á vegum atvinnulífsins. Eins og niðurstöður sýna getur petta verið vandkvæðum bundið, sérstaklega ef ekki er skýrt hvert innihald hvors prófs um sig er og einfaldlega er um endurtekin próf að ræða. Að einhverju leyti sýnir tilvist pessara tveggja prófa sterka tvískiptingu námsins og er enn eitt merkið um að iðnnám sé almennt ekki heildstætt nám, sem fer fram bæði í skóla og á vinnustað, og lýkur með sveinsprófi.

\section{Umræða}

Markmið rannsóknarinnar var að skoða viðhorf nýlegra sveina, iðngreinakennara og iðnmeistara til sveinsprófa. Nánar tiltekið átti að varpa ljósi á hvernig peir sjá sveinsprófið í samhengi við námið í heild, skoðun peirra á innihaldsréttmæti og framkvæmd prófanna.

Leiðin í námi iðnsveins eins og hún birtist í pessari rannsókn virðist oft á tíðum brotakennd. Námið fer bæði fram í skóla og á vinnustað og virðist samhæfing pessara hluta námsins oft ekki nægileg. Nemar hefja nám án pess að vera vissir um að peir geti lokið pví. Iðnnemar purfa sjálfir að útvega sér samning og skipuleggja nám sitt á vinnustað, en í mörgum tilfellum getur reynst erfitt að komast 
á samning og ljúka námi. Til pess að preyta sveinspróf og öðlast réttindi til starfa parf nemi að hafa lokið vinnustaðanámi, og pví getur núverandi kerfi torveldað endurnýjun í stétt iðnaðarmanna.

Ábyrgð á námi til iðnsveins virðist í raun óljós og erfitt að sjá hver á að bera hana. Samkvæmt lögum ber ráðherra menntamála ábyrgð á pessum málaflokki, en ábyrgð á framkvæmd er í raun óskýr. Úthýsing verkefna til starfsgreinaráða, sveinsprófsnefnda og fræðslustofnana hefur gert pað að verkum að boðleiðir eru langar og Ríkisendurskoðun (2017) hefur meðal annarra gagnrýnt flókna stjórnskipun starfsmenntamála. Samskipti kennara, meistara og sveinsprófsnefnda eru ekki formgerð og ekkert í kerfinu virðist gera kröfu um að pessir aðilar tali saman. Í einhverjum greinum voru samskipti til staðar um framkvæmd og skipulag sveinsprófa, en oft virtust meistarar ekki vera með í umræðunni. Viðmælendur voru pó fúsir til meiri samvinnu og samstarf hafði gefið góða raun par sem pað var til staðar.

Töluverð gagnrýni kom fram hjá viðmælendum á inntak sveinsprófa og ljóst er að margir telja innihaldsréttmæti ábótavant. Fram kom hjá mörgum viðmælendum að sveinsprófin væru ekki í takt við fagið og innihaldið endurspeglaði ekki pað sem nemendur hefðu lært í gegnum námið. Skýr skilgreind markmið virðast ekki vera notuð pegar kemur að vinnustaðanámi og afleiðingin er sú að ekki er endilega alltaf prófað á sveinsprófi í pví sem neminn hefur tileinkað sér í vinnustaðahluta námsins. vinnustað og sveinsprófsins.

Sveinsprófsnefndir eru skipaðar iðnaðarmönnum og ekki er hægt að gera ráð fyrir að peir hafi pekkingu á námsmatsfræðum. Hlutverk peirra er að semja og meta frammistöðu iðnnema á sveinsprófum og pví er mikilvægt að fyrir liggi skilningur á hvað purfi til að tryggja réttmæti prófa af pessu tagi. Í gegnum tíðina hefur verið reynt að koma til móts við petta með pví að halda námskeið í námsmatsfræðum fyrir sveinsprófsnefndir á vegum Mennta- og menningarmálaráðuneytisins og Iðunnar fræðsluseturs (Ólafur Grétar Kristjánsson, munnleg heimild). Einnig verður að gera pær kröfur að sveinsprófsnefnd eigi í virku samtali við bæði pá sem kenna fagið í skóla og á vinnustað, sem og starfsgreinaráð sem skilgreinir hæfnikröfur starfa. Samkvæmt niðurstöðum hér virðist pað sjaldgæft. Pó ber að leggja áherslu á að í pessari rannsókn var ekki rætt við pau sem sitja í sveinsprófsnefndum og starfsgreinaráðum, en pað er mikilvægt til að fá dýpri innsýn í viðfangsefnið og í frekari rannsóknum á pessu sviði ætti að líta sérstaklega til pessara aðila.

Sveinspróf eru lokamat á hæfni í iðnnámi. Til pess að prófin nái tilgangi sínum parf að tryggja innihaldsréttmæti peirra. Vinnustaðanám margra nema tekur ekki til allrar peirra færni og verkpátta sem krafist er á sveinsprófum og peirra hæfniviðmiða sem getið er um í Aðalnámskrá framhaldsskóla. Sveinspróf gegna mikilvægu hlutverki í iðnmenntakerfinu og eru hugsuð sem trygging á hæfni iðnaðarmanns til að gegna störfum innan fagsins. Ef pau eru samfélagsleg viðurkenning á hæfni fagmanns og ef pau eiga að gegna pví hlutverki sem peim er ætlað pá parf námið að mynda eina samfellda heild og sveinsprófið að vera samofið ferlinu.

Niðurstöður sýna að viðmælendur upplifa brotakennt kerfi par sem skóli er einn sjálfstæður hluti, vinnustaðir annar og sveinsprófið priðji. Skortur er á formlegum samskiptum og óljós ábyrgð gerir pað að verkum að námið myndar oft ekki samfellda heild. Pað er erfitt að ímynda sér hvernig sveinspróf geti verið réttmætt próf undir pessum kringumstæðum og sanngjarnt lokamat á hæfni fullnuma iðnaðarmanns. Раð má spyrja sig hvort sveinspróf eins og pau eru nú séu tímaskekkja og leita eigi annarra leiða við að staðfesta námsárangur iðnnema. Ljóst er að ekki virðist duga að ganga út frá „markmiðum aðalnámskrár og uppbyggingu námsins“" (reglugerð um sveinspróf nr. 698/2009, 12. gr.) og hæfnikröfum starfa sem liggja par til grundvallar. Lýsing á hæfni og markmiðum dugar stutt ef engar samræður eru innan menntakerfisins um hvað í peim felst, mögulegum útfærslum, leiðum til að ná settum markmiðum og viðmiðum um árangur.

\section{Aftanmálsgrein}

Greinin er byggð á meistaraprófsverkefni fyrsta höfundar og var annar höfundur leiðbeinandi. 


\section{The journeyman's examination in vocational education.}

Vocational education in Iceland is in general a dual system where a section of the programme takes place at an upper secondary school and another section at a workplace under apprenticeship contract. The so-called certified trades are a major aspect of vocational education in Iceland, where the programme ends with a journeyman's examination, legally required for working in the field. This study investigates the journeyman's examination in its capacity as a legal and social recognition of professional skill and a final assessment of vocational studies. The journeyman's examinations are professional qualifications undertaken after graduation from school and having completed the workplace section of the programme. An independent journeyman's examination committee is responsible for creating, holding, and evaluating these examinations. A journeyman's licence is considered a good measurement of professional skill and provides the legal certification to work independently in a trade. The objective of this research is to understand how those who work within the vocational education system, journeymen, teachers and master craftsmen, view the journeyman's examination. In particular, the research questions concern how they view the examinations in the context of the programme as a whole, their opinion on the internal validity of the examination, and their experience and view of the process of taking the journeyman's examination.

To answer these questions four trades were selected as representative of the various programme types found among the certified trades, in terms of duration of the workplace period and the sequencing of the school and workplace periods. A total of 24 participants were interviewed, six within each trade: recently graduated journeymen $(\mathrm{n}=8)$, teachers at upper secondary schools $(\mathrm{n}=8)$, and master craftsmen in charge of apprentices at workplaces $(\mathrm{n}=8)$. The interviews were semi-structured and covered various topics relating to vocational education, among them the journeyman's examination which is of interest here. The interviews were recorded and transcribed verbatim for analysis. Thematic analysis (Braun \& Clarke, 2006, 2013) was used to code the data and organize themes in accordance with the research questions.

The findings suggest insufficient content validity of journeyman's examinations; that is to say, what is being taught in the programme as a whole, in school and workplace, is not being evaluated. Although not unanimous in what the journeyman's examination should contain, most interviewees agreed that those examinations were not in accordance with current practices in the trade in general and students' workplace experiences in particular. In part this seems related to the dual nature of the programmes and periods at school and workplaces. These appear to be insufficiently integrated, often resulting in gaps between periods and the loss of knowledge and skill. Also, curricula do not clearly define what should be taught during the workplace period of the programme. As a result, there does not seem to be a consensus within trades as to what competences students should have acquired after completing this part of the programme. It is quite difficult to ensure the content validity of an examination when there is no clear consensus on the content, and this is particularly problematic in case of a summative master's examination. The findings also show that the legal framework on which journeyman's examinations are based is too complicated, needing revision and improvement. In particular, there is a need for stakeholders to be more engaged and involved throughout the programme as a whole. The teachers and master craftsmen interviewed expressed clear interest in a formalised conversation and contact with the journeyman's examination committee, and the results indicate that where communication takes place, there is better accord and agreement about the examinations.

In sum, the results show that journeymen's study programmes in a double system of certified trade are too restricted in scope, there is no clear consensus as to what workplace training should include, and, besides, lack of communication complicates the matter. 
Therefore, improvements are needed to ensure that the journeyman's examinations measure the knowledge, competence and skill a journeyman is expected to acquire in vocational programmes relating to certified trades in Iceland.

Keywords: Vocational education, journeyman's examination, upper secondary education

\section{Um höfunda}

Guðfinna Guðmundsdóttir (gudfinna.gudmundsdottir@gmail.com) er kennari við Kársnesskóla í Kópavogi og Fjölbrautaskólann í Breiðholti. Hún lauk sveinsprófi í matreiðslu árið 1991 frá Hótel- og veitingaskóla Íslands og iðnmeistaraprófi árið 1993 frá Iðnskólanum í Hafnarfirði. Hún lauk kennslurétttindaprófi frá Háskóla Íslands árið 2013, B.Ed.-gráðu í kennslufræði verk- og starfsmenntunar 2016 og meistaraprófi í fræðslustarfi og nýsköpun frá Háskóla Íslands 2020.

Elsa Eiríksdóttir (elsae@hi.is) er dósent við Menntavísindasvið Háskóla Íslands. Hún lauk BA-gráđu í sálfræði frá Háskóla Íslands 1999 og meistara- og doktorsprófi í verkfræðilegri sálfræði 2007 og 2011 frá Georgia Institute of Technology. Rannsóknir hennar hafa helst snúið að hugrænum ferlum í námi, yfirfærslu pekkingar og færni, verklegu námi og starfsnámi.

\section{About the authors}

Guðfinna Guðmundsdóttir (gudfinna.gudmundsdottir@gmail.com) is a teacher at Kársnesskóli in Kópavogur (elementary school) and Fjölbrautaskólinn in Breiðholt (upper secondary school). She graduated as a journeyman in culinary arts in 1991 from The Culinary School of Iceland and as a master craftsman in 1993 from the Vocational School in Hafnarfjörður. She received a diploma in vocational pedagogy from the University of Iceland in 2013, a B.Ed. degree in vocational pedagogy in 2016, and a master's degree in educational work and innovation from the University of Iceland in 2020.

Elsa Eiríksdóttir (elsae@hi.is) is an associate professor at the University of Iceland, School of Education. She completed a BA degree in psychology from the University of Iceland in 1999 as well as a master's degree and a PhD in engineering psychology from Georgia Institute of Technology in Atlanta in 2007 and in 2011, respectively. Her research interests include learning, transfer of training, skill acquisition, and vocational education and learning.

\section{Heimildir}

Atli Harðarson. (2012). Hugmyndir um námsmarkmið í nýrri Aðalnámskrá framhaldsskóla. Skirnir, 186(1), 215-222.

Braun, V. og Clarke, V. (2006). Using thematic analysis in psychology. Qualitative Research in Psychology, 3(2), 77-101. doi:10.1191/1478088706qp063oa

Braun, V. og Clarke, V. (2013). Successful qualitative research: A practical guide for beginners. London: SAGE.

Bryman, A. (2012). Social research methods (4. útgáfa). Oxford: Oxford University Press.

Elsa Eiríksdóttir. (2017). Nám í skóla og á vinnustað: Viðhorf og reynsla sveina, kennara og meistara af tvískiptu kerfi löggiltra iðngreina. Tímarit um uppeldi og menntun, 26(1-2), 43-64. 
Elsa Eiríksdóttir. (2018). Variations of the vocational education and training dual system in Iceland. Í S. Choy, G.-B. Wärwik, V. Lindberg og I. Berglund (ritstjórar), Integration of vocational education and training experiences: Purposes, practices and principles (bls. 145-164). Singapore: Springer.

Iðan fræðslusetur. (e.d.). Námskeið og fræðsla. Sótt af https://www.idan.is/

Iðnaðarlög nr. 42/1978.

Kilbane, C. R. og Milman, N. B. (2014). Teaching models: Designing instruction for 21st century learners. Boston, MA: Pearson.

Lög um framhaldsskóla nr. 92/2008.

Menntamálastofnun. (e.d.). Staðfestar námsbrautarlýsingar. Sótt af https://mms.is/stadfestarnamsbrautalysingar

Mennta- og menningarmálaráðuneyti. (2012). Aðalnámskrá frambaldsskóla 2011: Almennur hluti. Reykjavík: Höfundur.

Mennta- og menningarmálaráðuneytið. (2020). Tryggja aðgang iðnnema að vinnustaðanámi. Sótt af https://www.stjornarradid.is/efst-a-baugi/frettir/stok-frett/2020/11/20/Tryggja-adgang-idnnema-advinnustadanami-/?fbclid=IwAR3KNkdrHJQJ17j0EjFotTpeQckg5lo4fKDpzrTvvMLUbhayx44ISD G5e_0

Ólafur Grétar Kristjánsson. (1995, 5. nóvember). Er sveinsprófið tímaskekkja? Morgunblaðið, bls. 28.

Rafmennt. (e.d.). Námssamningar. Sótt afhttps://www.rafmennt.is/is/um-sveinsprof/namssamningar

Ragnar Wessman. (2010). Að tryggja áreiðanleika og réttmati við mat á bragði i verklegum prófum matvalagreina (meistararitgerð). Sótt af http://hdl.handle.net/1946/5649

Reglugerð um löggiltar iðngreinar nr. 940/1999.

Reglugerð um skipan og störf starfsgreinaráða nr. 711/2009.

Reglugerð um sveinspróf nr. 698/2009.

Reglugerð um vinnustaðanám og starfspjálfun nr. 840/2011.

Ríkisendurskoðun. (2017). Starfsmenntun á frambaldsskólastigi: Skipulag og stjórnsýsla. Reykjavík: Höfundur.

Samtök iðnaðarins. (2019). Kynningar- og samráðsfundur um rafræna ferilbók. Sótt af https://www. si.is/frettasafn/kynningar-og-samradsfundur-um-rafraena-ferilbok

Stiggins, R. J. (2001). Student-involved classroom assessment (3. útgáfa). Upper Saddle River, NJ: Merrill Prentice-Hall.

Védís Grönvold og Sveinn Aðalsteinsson. (2016). Úttekt á framkvamd og gaðum starfsnáms á vinnustöðum. Reykjavík: Mennta- og menningarmálaráðuneytið.

Waugh, C. K. og Gronlund, N. E. (2013). Assessment of student achievement. Boston: Pearson.

Guðfinna Guðmundsdóttir og Elsa Eiríksdóttir. (2020).

Sveinspróf í iðnmenntakerfinu: Tímaskekkja eða réttmætt mat á hæfni?

Netla - Veftímarit um uppeldi og menntun. Menntavísindasvið Háskóla Íslands.

Sótt af http://netla.hi.is/serrit/2020/menntavika_2020/07.pdf

DOI: https://doi.org/10.24270/serritnetla.2020.13 